\title{
Imperatives for the formation and development of the circular economy and global waste management
}

\author{
Inna Khomenko $^{1 *}$, Marina Vuychenko $^{2}$, Maryna Gomeniuk $^{2}$, Yurii Mazur ${ }^{2}$, and Oksana \\ Haidai $^{2}$ \\ ${ }^{1}$ Chernihiv Polytechnic National University, Department of Theoretical and Applied Economics, 95, \\ Shevchenko Str., 14035 Chernihiv, Ukraine \\ ${ }^{2}$ Uman National University of Horticulture, 1 Instytutska str., 20305 Uman, Ukraine
}

\begin{abstract}
The world ecological problem of waste accumulation, environmental pollution and the need to develop a circular economy are described. The aim of the article is to show the advantage of using a circular economy in the management of the national economy. It is substantiated that resource management should radically change from a linear model of accept-use-dispose to a more stable, circular model. It is proved that the principles of circular economy are not based on the management of material and waste flows, but on more valuable methods, such as maintenance, recycling and reuse. Different models of circular economy and their shortcomings are considered. Based on practical world experience in implementing the concept of circular economy, 5 main circular business models are identified. It has been established that circular supply chains that minimize waste and seek to reuse, repair and recycle where waste cannot be prevented should be more sustainable than the linear systems they replace. It was found that in the absence of effective resource management, the current environmental situation will lead to fatal consequences, which confirms the need for public administration to ensure the use of a circular economy.
\end{abstract}

\section{Introduction}

The modern world paradigm of sustainable development is aimed at the production of goods and services with minimal costs of available resources. The introduction of a circular economy allows to increase the efficiency of resource use through the introduction of optimization solutions and simultaneous compliance with the principles of environmental friendliness. Circular economy allows to function and develop efficient business models and startups, and everything produced and used by businesses can be completely processed within the production chain, adhering to the minimum level of waste. The circular economy model synthesizes several basic ideas. These include Walter Stachel's functional economics of services (efficiency economics) [1]; cradle-to-cradle design philosophy by William McDonough and Michael Braungart [2]; biomimicry formulated by Janine Benus [3];

\footnotetext{
*Corresponding author: innakhomenko28@gmail.com
} 
industrial ecology Reed Lifset and Thomas Graedel [4]; natural capitalism - Amori and Hunter Lovins and Paul Hawken [5]; and the blue economy approach described by Gunter Pauli [6].

F. Loazel, head of the Renault plant in Huazi-le-Roi [7], noted that the circular economy allows a new approach to the means of labor and try to recycle them after the expiration date, to turn them into a resource for production by implementing new ideas. M. Orfelen, Manager of the Circular Economy and Waste Management Department of the National Environment and Resources Administration (ADEME, the Netherlands), said that With the introduction of the basic provisions of the circular economy, the profitability of production at enterprises increases. This is due to the reduction of raw material costs and waste management at the end of the production cycle. The profitability indicator is also influenced by the factor of selling environmentally friendly products as a basis for corporate social responsibility [8].

\section{Waste management in the world and in Ukraine}

Mankind has always met its needs and explored new technologies. This not only contributed to the scientific and technological progress, but also had a dramatic anthropogenic impact on the man-made environment, which led to global changes, namely significant global environmental problems. By introducing a circular economy into the national one, it is necessary to reduce the impact of economic activity on environmental security. The World Economic Forum's annual report on global risks states that starting in 2020, the global economic and political gap will widen, which will only exacerbate global environmental problems. Humanity is now most in need of world leaders and large companies to develop and implement measures to address threats to climate, the environment, health and technological systems. Therefore, it is necessary to use all effective methods to promote the concept of a circular economy, to identify and eliminate potential risks to economic, environmental and social operations in the process of rapid transition to a circular economy.

The exploitation of natural resources is accelerating in the face of declining resources, while humanity at the same time generating ever-increasing waste streams and polluting the environment. The global use of resources per capita is much greater than the recovery of resources per capita (Fig. 1).

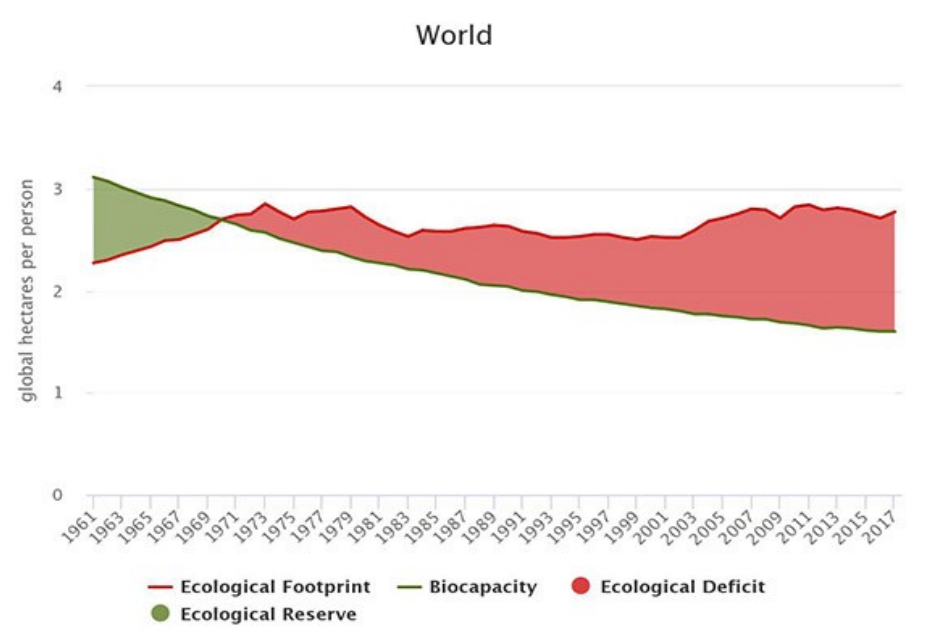

Fig. 1. The number of available resources and the number of resources used per person [9]. 
The current level of global consumption and the associated over-reliance on waste and emissions rather than reuse and recycling make global environmental security impossible (Tables 1-3). The ecological ceiling of planetary boundaries has been overcome, and humanity risks destabilizing the geological conditions on which our society depends. However, the increasing use of resources for many people has strengthened social foundations, incomes and well-being. However, people's long-term well-being depends on a healthy environment, providing the resources needed to meet basic human needs, including access to clean water, food and shelter.

Table 1. Waste generation and management.

(Thousand tons)

\begin{tabular}{|c|c|c|c|c|c|}
\hline Years & $\begin{array}{c}\text { The amount of } \\
\text { waste } \\
\text { generated }\end{array}$ & $\begin{array}{c}\text { The amount } \\
\text { of waste } \\
\text { disposed of }\end{array}$ & $\begin{array}{c}\text { The } \\
\text { amount of } \\
\text { incinerated } \\
\text { waste }\end{array}$ & $\begin{array}{c}\text { The amount of } \\
\text { waste disposed } \\
\text { of in specially } \\
\text { designated } \\
\text { places and } \\
\text { facilities }\end{array}$ & $\begin{array}{c}\text { The total amount of } \\
\text { waste accumulated } \\
\text { during operation, in } \\
\text { specially designated } \\
\text { places and facilities }\end{array}$ \\
\hline 2015 & 312267,6 & 92463,7 & 1134,7 & 152295,0 & 12505915,8 \\
\hline 2016 & 295870,1 & 84630,3 & 1106,1 & 157379,3 & 12393923,1 \\
\hline 2017 & 366054 & 100056,3 & 1064,3 & 169801,6 & 12442168,6 \\
\hline 2018 & 352333,9 & 103658,1 & 1028,6 & 169523,8 & 12972428,5 \\
\hline 2019 & 441516,5 & 108024,1 & 1059,0 & 238997,2 & 15398649,4 \\
\hline
\end{tabular}

Table 2. Costs of production (goods, services).

\begin{tabular}{|c|r|r|r|c|}
\hline \multirow{2}{*}{ Years } & \multirow{2}{*}{$\begin{array}{c}\text { Costs of production } \\
\text { (goods, services) } \\
\text { thousand USA }\end{array}$} & \multicolumn{3}{|c|}{ Material costs and costs of services used in production } \\
\cline { 3 - 5 } & 86939421,3 & thousand USA & $\begin{array}{c}\text { to total } \\
\text { costs in \% }\end{array}$ & growth rate, \% \\
\hline 2015 & 98569391,2 & 64484732,46 & 74,2 & 127,17 \\
\hline 2016 & 125899567 & 73142385,36 & 74,2 & 113,43 \\
\hline 2017 & 152248712 & 94445173,24 & 75,0 & 129,13 \\
\hline 2018 & 166975283 & 113044753,9 & 74,3 & 119,69 \\
\hline 2019 & 119177142,7 & 71,4 & 105,42 \\
\hline
\end{tabular}

Table 3. Dynamics of the volume of waste generated from economic activity.

\begin{tabular}{|c|c|c|c|c|}
\hline Years & $\begin{array}{c}\text { Waste } \\
\text { generated, in } \\
\text { total, } \\
\text { thousand tons }\end{array}$ & $\begin{array}{c}\text { Gross domestic } \\
\text { product at constant } \\
2011 \text { prices for PKS, } \\
\text { billion dollars USA }\end{array}$ & $\begin{array}{c}\text { The volume of generated } \\
\text { waste from economic } \\
\text { activity per unit of GDP at } \\
\text { constant prices in 2011 for } \\
\text { PKS, kg / 1000 dollars USA }\end{array}$ & $\begin{array}{c}\text { Growth } \\
\text { rate, \% }\end{array}$ \\
\hline 2015 & 312267,6 & 319,8 & 957,5 & 97,35 \\
\hline 2016 & 295870,1 & 327,6 & 883,8 & 92,30 \\
\hline 2017 & 366054,0 & 335,7 & 1073,0 & 121,41 \\
\hline 2018 & 352333,9 & 346,9 & 999,7 & 93,17 \\
\hline 2019 & 441516,5 & - & - & - \\
\hline
\end{tabular}

Analyzing the dynamics of changes in production costs and changes in the amount of waste generated (Table 2-3), we can say that the cost of production increases more than the amount of waste generated.

Resource production and waste generation have now reached such proportions that lead to unprecedented environmental degradation, climate change and pollution - thus violating basic human rights and needs. The boundaries of supporting long-term environmental and socio-economic stability have been crossed. Radical changes are needed in the ways of organizing waste and resource flows, resource economy. 


\section{Results and discussion}

Given the diversity of conceptual roots, it is not surprising that the circular economy is described in more than a hundred ways. These diverse concepts relate to better use of the resources presented here in the words of the Ellen MacArthur Foundation: "Going beyond the current mining industry model of' take, manufacture and dispose', the circular economy is designed to be restorative. Relying on system-wide innovations, they aim to rethink products and services for waste design, minimizing the negative consequences. Supported by the transition to renewable energy sources, the circular model builds economic, natural and social capital [11].

Circular supply chains that minimize waste and seek to reuse, repair and recycle where waste cannot be prevented must be more sustainable than the linear systems they replace; the ability of the circular economy to promote sustainable development is widely recognized, but requires further conceptual development, supported by empirical evidence. Most productive consumption systems cannot circulate $100 \%$ of resources, for example, due to quality losses and energy needs, and therefore new inflows of resources from the natural environment will remain necessary even in a circular economy. Moreover, the transition to a circular economy requires innovative technologies and business models, as well as cultural change. It takes time to move away from current systems focused on linear and economic growth to more circular systems that promote a healthy environment and greater equality. In the transition phase, it is necessary to implement a circular economy, which allows developing business through more efficient use of resources and contributing to the environment and society, maintaining the technical value, functional qualities of materials circulating through the production-consumption system. The circular economy is depicted in a widely used butterfly diagram (Fig. 2) developed by Braungart and McDonough [2] for the Ellen MacArthur Foundation.

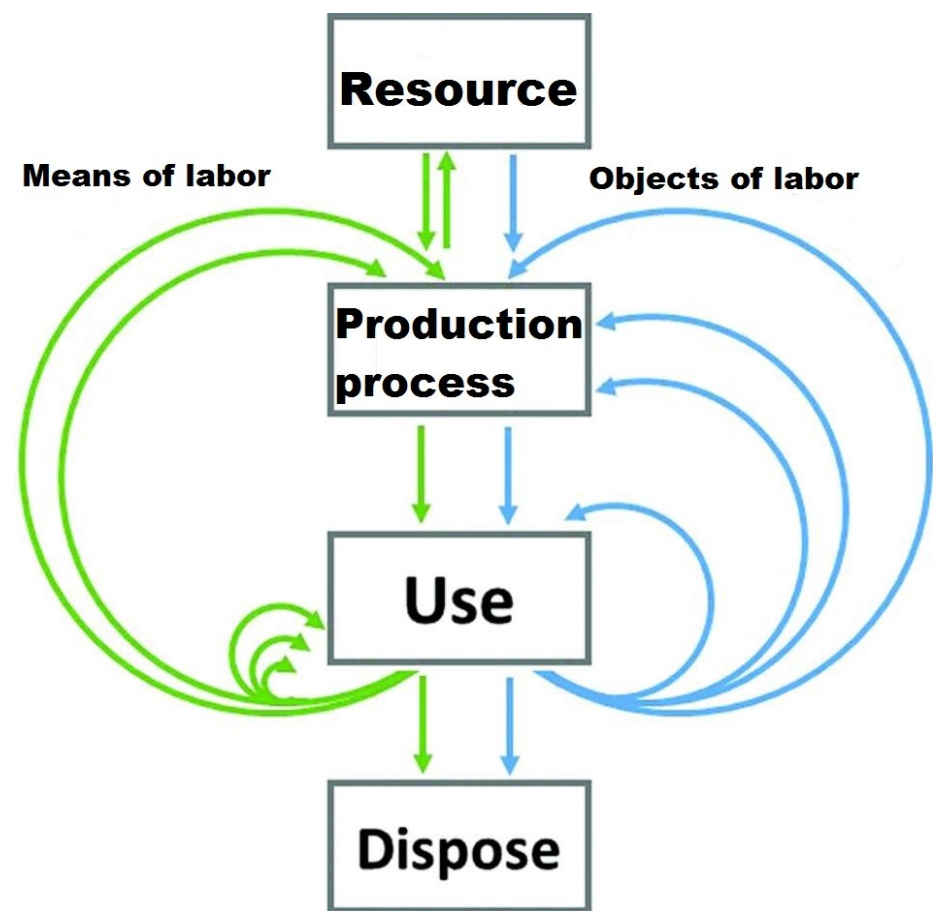

Fig. 2. Simplified diagram of a butterfly [2]. 
The diagram shows the individual streams of "biological" and "technical" materials. "Technical" materials are limited and are used in a closed loop system through sharing, maintenance, reuse, recycling and recycling of products. Conversely, 'biological' materials can be recovered and organized in a system of open resource cycles that are cascaded through subsequent stages of extraction, biomaterial production, energy recovery, and nutrient return to the biosphere to ensure the next production cycle of primary crops.

The Ellen MacArthur Foundation [11] has provoked a global movement towards a circular economy, inspiring governments and companies around the world. The butterfly chart was the key in involving stakeholders from all walks of life in the circular economy.

However, there are important shortcomings of the butterfly diagram that become apparent during the implementation of circular economy practices. First, the extractive and primary materials processing sectors are largely excluded from the chart. It is important to consider these sectors as part of a circular economy, as they are the world's largest waste producers and energy consumers. Second, materials and products usually contain more than one type of resource by nature or design; biological and technical materials do not flow in separate cycles and are often mixed.

The waste recovery program [12] proposed a new model of the circular economy (Fig. 3 ): the system of production and consumption is built into the wider biophysical environment, recognizing people as an integral part of the environment. In the figure, green arrows indicate natural materials; blue arrows indicate industrial materials. Humans extract natural materials from the biophysical environment, convert, use and dispose of industrial materials within the production-consumption system. At the end of use, materials and products can circulate directly back in the production and consumption cycle or stored in a controlled environment in resource recovery systems. Industrial materials that are no longer needed for production should be safely returned to the biophysical environment and facilitated for their reintegration into natural capital reserves that can provide future production-consumption cycles. This new model of a circular economy, embracing the mixed nature of materials, offers an effective starting point for developing government strategy, business practices, and innovative technologies and resource management systems.

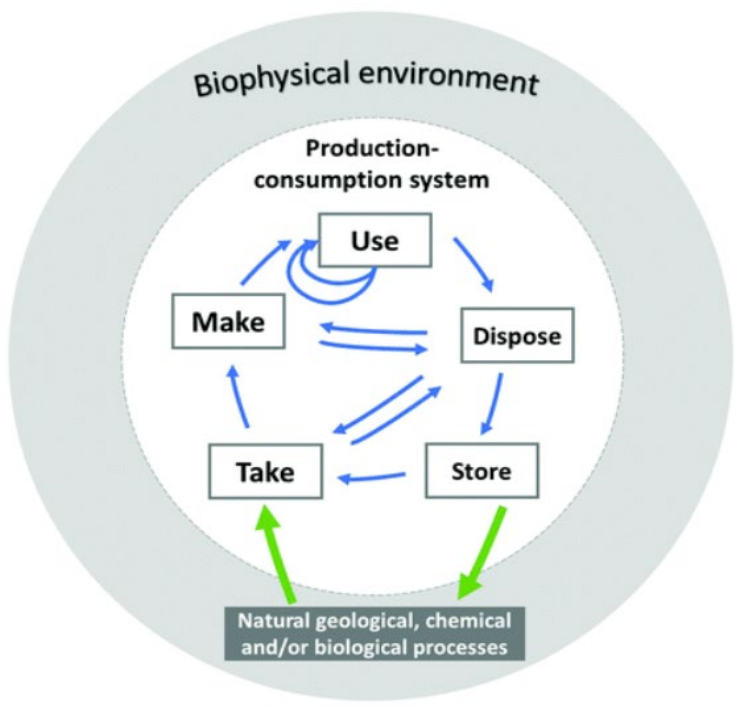

Fig. 3. Simplified integrated resource flow model for the circular economy [12]. 
Regardless of the environment, the possible risks of transition to a circular economy towards environmental, economic and social development are interrelated and interdependent, ignoring one factor can lead to fluctuations in another or even all factors, leading to increased losses in other systems [13-18]. This situation requires a comprehensive and systematic approach to managing such possible events to prevent them from occurring. For example, a reduction in production will reduce staff, which in turn will reduce revenue. In turn, most of the production and construction of the entire economic system, which meets the requirements of the circular economy, will take place within the city, which can lead to irrational urbanization and create risks to the environment in terms of sanitation and health. Thus, as noted above, in the absence of effective risk management for the transformation of the economic system, this situation will lead to fatal consequences, which confirms the need for public administration to ensure the implementation of a circular economy (Fig. 4) [19-23].

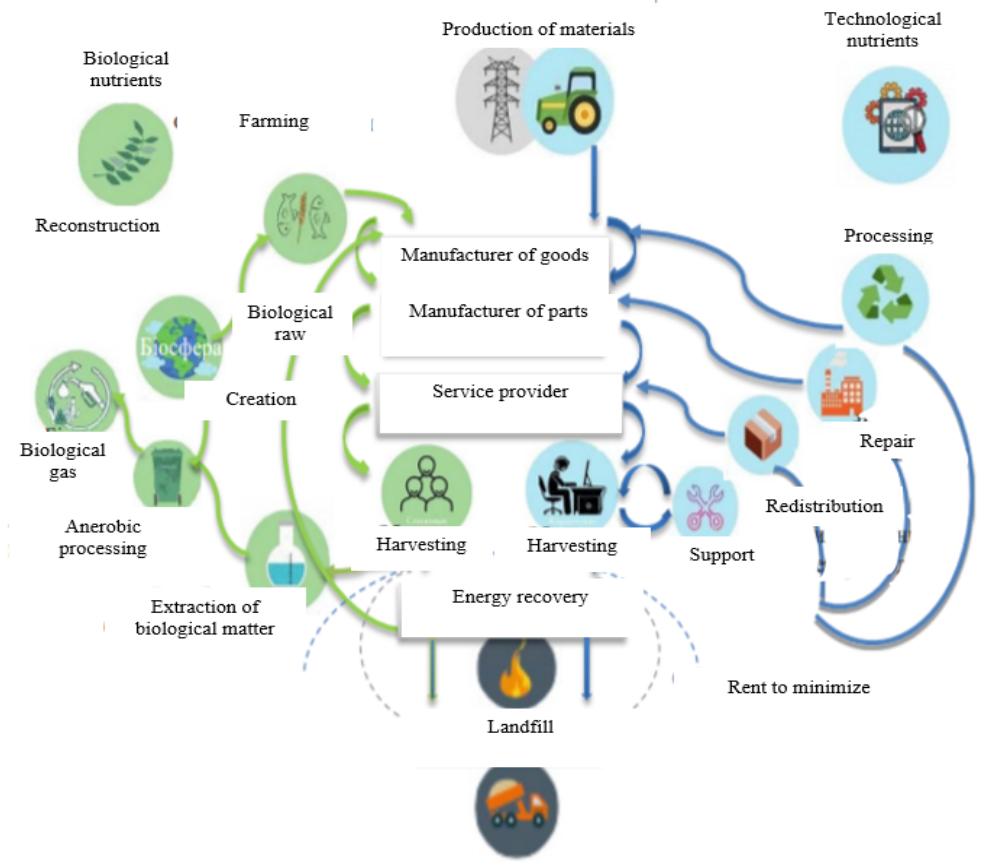

Fig. 4. Circular economy as an industrial system $[11,13]$.

Based on practical world experience in implementing the concept of circular economy, we can identify 5 main circular business models [24-27]:

1. Circular suppliers are a way to replace limited resources with renewable sources. The basis is to provide fully recyclable resources or other resources that are subject to biological destruction (decomposition).

2. Resource's recovery is a model in which resources can be restored and reused through innovation. This helps to avoid loss of resources and increase the profitability of production through reverse flow.

3. Sharing platforms are a model for exchanging or sharing goods or assets. Also provides interaction between product users.

4. Product life extension - a model that, due to modernization, restoration, renewal of the company extends the product life cycle. 
5. Product as a service - a model that provides an alternative method of purchasing products - its use in the form of "rent" with payment on the spot (through leases, leasing, etc.).

The relationship between existing circular business models is shown in Figure 5. Circular business strategies are already being implemented by a number of leading companies: for example, RollsRoyce sells power, not engines, hourly; Michelin offers tires for rent trucks, assigning a fee to their owners for the kilometers traveled; Xerox sells copies made, not copiers; Houdini offers rental, not sale sports equipment; Philips rents intelligent lighting systems instead of sales; Renault takes used engines and their components, restores them and sells them as replacement engines [28-30].

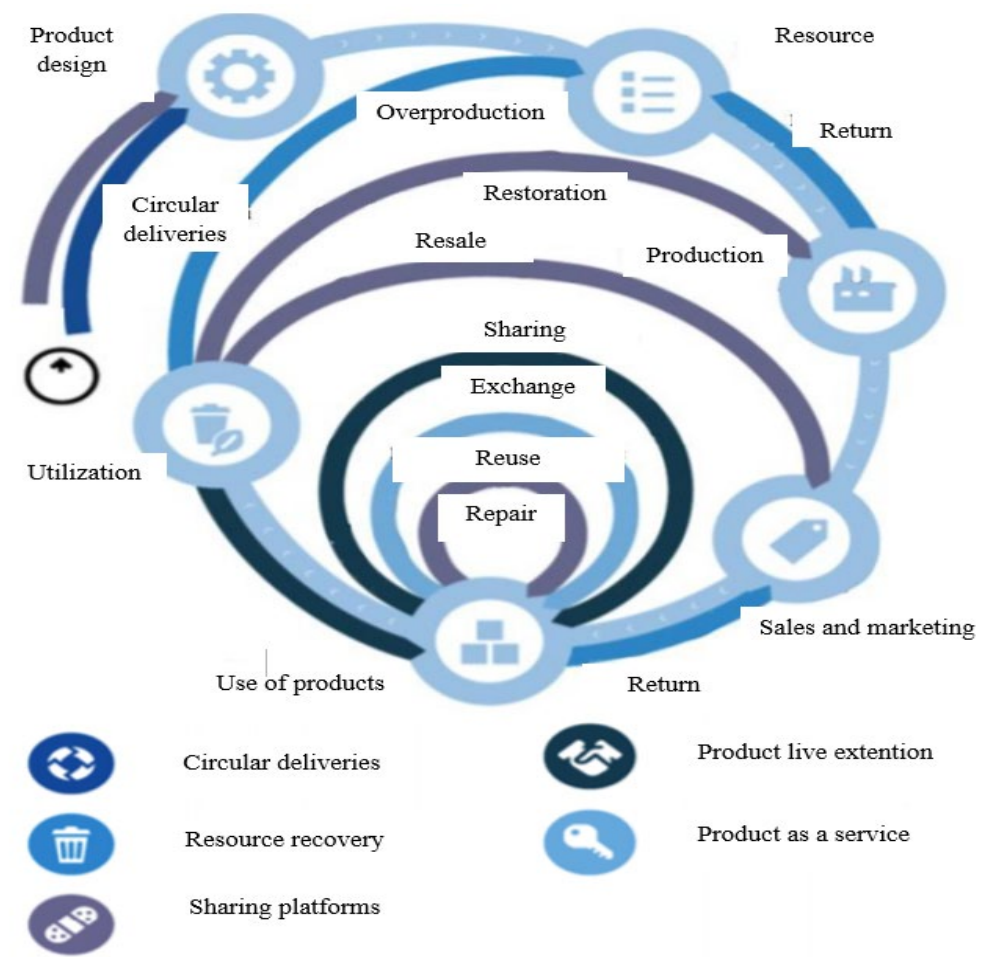

Fig. 5. Relationship of existing circular business models [31].

\section{Conclusions}

Unlike the traditional economy, the circular model is the most successful way to save resources and materials, and therefore is the path to sustainable economic growth.

The principles of the circular economy are not based on the management of material and waste flows, but on more valuable approaches such as maintenance, recycling and reuse.

Governments can and perhaps should do more to ensure a sustainable circular economy. However, there is a general consensus that the government cannot make the radical changes that the world needs. The cooperation of all subjects of the circular model of the economy is a key factor for its implementation. Joint action by all relevant stakeholders in society, from government to companies, civil society and academia, is critical. 
It is necessary to change the trend of increasing resource use and increasing the level of waste accumulation, as this is currently the main challenge facing modern society and is a condition for a secure future.

This work was conducted within the projects "Socio-economic problems of sustainable development of the region" (State registration No. 0115U000891).

\section{References}

1. Stahel, W. (2016). The circular economy. Nature, 531, 435-437.

2. Braungart, M., \& McDonough, W. (2009). Cradle to Cradle: Play the way we do things. Vintage, London.

3. Benyus, J. (1997). Biomimicry: Innovation inspired by nature. New York: Harper Perennial.

4. Graedel, T., \& Lifset, R. (2016). Industrial Ecology's First Decade. In Taking Stock of Industrial Ecology, edited by R. Clift and A. Druckman. Springer International.

5. Hawken, Paul, Lovins, Hunter, \& Lovins, Amory. (1999). Natural Capitalism: Creating the Next Industrial Revolution. New York: Little, Brown \& Company.

6. Pauli, G. A. (2010). The Blue Economy: 10 Years, 100 Innovations, 100 Million Jobs. Paradigm Publications, New Mexico, USA.

7. Guldmann, E. (2016). Best Practice Examples of Circular Business Models. The Danish Environmental Protection https://www2.mst.dk/Udgiv/publications/2016/06/978-87-93435-86-5.pdf

Agency.

8. Mikhno, I., Koval, V., Shvets, G., Garmatiuk, O., \& Tamošiūnienè, R. (2021). Green Economy in Sustainable Development and Improvement of Resource Efficiency. Central European Business Review, 10(1), 99-113. https://doi.org/10.18267/j.cebr.252

9. United Nations Environment Program (UNEP). (2016). Global Material Flows and Resource Productivity: Evaluation Report for the UNEP International Resource Group. http://unep.org

10. State Statistics Service of Ukraine (2020). http://www.ukrstat.gov.ua

11. Ellen MacArthur Foundation. (2018). What is a circular economy? Cowes: Ellen MacArthur Foundation.

12. Velenturf, APM, Archer, SA, Gomes, H., Christgen, B., Lag-Brotons, AJ, \& Purnell, P. (2019). Circular Economics and Integrated Resources Issues, Sci. General Environment, 689, 963-969.

13. Clubofrome (2017). Research report "Circular economy and benefits for society". http://www.clubofrome.org.ua

14. Arsawan, I.W.E., Koval, V., Rajiani, I., Rustiarini, N.W., Supartha, W.G. and Suryantini, N.P.S. (2020). Leveraging knowledge sharing and innovation culture into SMEs sustainable competitive advantage. International Journal of Productivity and Performance Management. (in press). https://doi.org/10.1108/IJPPM-04-2020-0192

15. Lacy, P., Keeble, J., McNamara, R., Rutqvist, J., Haglund, T., Cui, M., Cooper, A., Pettersson, C., Eckerle, K., Buddemeier, P., Sharma, A., \& Senior, T. (2014). Circular Advantage: Innovative Business Models and Technologies to Create Value in a World without Limits to Growth. Accent. Strateg. 24. https://www.accenture.com

16. Koval, V., Mikhno, I., Hajduga, G. \& Gaska, K. (2019). Economic efficiency of biogas generation from food product waste. E3S Web Conf. 100, 00039. 
17. Bourguignon, D. (2018). Circular economy package. Four legislative proposals on waste. Briefing. EU Legislation in Progress. http://www.europarl.europa.eu/RegData

18. Khomenko, IO., Babachenko, L.V., \& Padiy, Y.V. (2017). Problems and directions of solid waste processing in Ukraine. Economy and society, 12, 454-458.

19. Benson, D., \& Monciardini, D. (2018). Governing the circular economy: multi-level comparative analysis. Circular economy disruptions - past, present and future. 17th19th . Exeter, UK: June., 983-1003. https://doi.org/10.1080/09644016.2019.1673996

20. Geissdoerfer, M., \& et al., (2017). The circular economy - a new sustainability paradigm? Journal of Cleaner Production, 143, 757768. https://doi.org/10.1016/j.jclepro.2016.12.048

21. Ghisellini, P., Cialani, C., \& Ulgiati, S. (2016). A review on circular economy: the expected transition to a balanced interplay of environmental and economic systems. Journal of Cleaner Production, 114, 11-32. http://www.iaeng.org/publication/WCE2016/WCE2016_pp763-768.pdf

22. Pardo, R., \& Schweitzer, J.P. (2018): 'A long-term strategy for a European circular economy - setting the course for success', Policy Paper produced for the Think2030 project, Brussels, November 2018.

23. Dan, H. (2019). Culturally green-An investigation into the cultural determinants of environmental performance. Forum Sci. Oecon. 7, 107-126.

24. Baklanova, O., Petrova, M., Koval, V. (2020). Institutional Transmission in Economic Development. Ikonomicheski Izsledvania, 29(1), 68-91.

25. Flynn, A., \& Hacking, N. (2019). Setting standards for a circular economy: a challenge too far for neoliberal environmental governance? Journal of Cleaner Production, 212, 1256-1267. https://doi.org/10.1016/j.jclepro.2018.11.257

26. Dankeieva, O., Solomianiuk, N., Strashynska, L., Fiedotova, N., Soloviova, Y., \& Koval, V. (2021). Application of Cognitive Modelling for Operation Improvement of Retail Chain Management System. TEM Journal, 10(1), 358-367. https://doi.org/10.18421/TEM101-45

27. Korhonen, J., \& Et al. (2018). Circular Economy: The Concept and its Limitations. Ecological Economics, 37-46. https://doi.org/10.1016/j.ecolecon.2017.06.041

28. Kvasha, S., Pankratova, L., Koval, V., \& Tamošiūnienė, R. (2019). Illicit financial flows in export operations with agricultural products. Intelellectual Economics, 13(2), 195-209.

29. Yankovyi, O., Goncharov, Yu., Koval, V., \& Lositska, T. (2019). Optimization of the capital-labor ratio on the basis of production functions in the economic model of production. Naukovyi Visnyk Natsionalnoho Hirnychoho Universytetu, 4, 134-140.

30. Šebestová, J., \& Sroka, W. (2020). Sustainable development goals and SME decisions: The Czech Republic vs. Poland. J. East. Eur. Cent. Asian Res., 7, 39-50.

31. Beroc (n.d.) Circular economy in action: forms of organization and best practices. http://www.beroc.by/webroot/delivery 